\title{
Growth, mortality and reproduction of the blue tilapia Oreochromis aureus (Perciformes: Cichlidae) in the Aguamilpa Reservoir, Mexico
}

\author{
Emilio Peña Messina ${ }^{1}$, Raul Tapia Varela ${ }^{1}$, José Iván Velázquez Abunader ${ }^{2}$, Alma Araceli Orbe
} Mendoza $^{3}$ \& Javier Marcial de Jesús Ruiz Velazco Arce ${ }^{1,2}$

1. Dirección de Fortalecimiento de la Investigación, Universidad Autónoma de Nayarit. Cd. de la Cultura Amado Nervo s/n 63255, Tepic, Nayarit, Mexico; pemess@nayar.uan.mx , raultapia539@hotmail.com, marcialj@nayar.uan.mx

2. Departamento de Pesquerías y Biología Marina, Centro Interdisciplinario de Ciencias Marinas (CICIMAR-IPN). Av. Instituto Politécnico Nacional s/n Playa Palo Santa Rita. Apdo. Postal 592, La Paz, B.C.S. 23000, México. Tel. +52 (612) 123 4658, Fax. +52 (612) 122 5322; jvelazqueza@ipn.mx

3. Dirección General de Ordenamiento Pesquero y Acuícola, Comisión Nacional de Acuacultura y Pesca (CONAPESCASAGARPA). Av. Camarón Sábalos s/n Esq. Tiburón. Fracc. Sábalo Country Club. Mazatlán, Sinaloa 82100, Mexico; araceliorbe@yahoo.com.mx

Received 05-XI-2009. C Corrected 09-VII-2010. Accepted 10-VIII-2010.

\begin{abstract}
Tilapia production has increased in Aguamilpa Reservoir, in Nayarit, Mexico, in the last few years and represents a good economic activity for rural communities and the country. We determined growth parameters, mortality and reproductive aspects for 2413 specimens of blue tilapia Oreochromis aureus in this reservoir. Samples were taken monthly from July 2000 through June 2001, of which 1371 were males and 1042 were females. Standard length (SL) and total weight (TW) were measured in each organism. The SL/TW relationships through power models for sexes were determined. The growth parameters $L_{\infty}, k$, and $t_{0}$ of the von Bertalanffy equation were estimated using frequency distribution of length through ELEFAN-I computer program. Finally the reproductive cycle and size of first maturity were established using morph chromatic maturity scale. The results suggested that the males and females had negative allometric growth $(b<3)$. Significant differences were found between SL/TW model for the sexes, suggesting separate models for males and females. Results indicate that there are no differences in growth rates between sexes; the proposed parameters were $L_{\infty}=43.33 \mathrm{~cm}$ standard length, $k=0.36 /$ year and $t_{0}=-0.43$ years. Natural and fishing mortality coefficients were $0.83 /$ year and 1.10 year, respectively. The estimated exploitation rate $(0.57 /$ year $)$ suggested that during the study period the fishery showed signs of overfishing. Blue tilapia reproduces year-round; the highest activity occurs from January through May and size of first maturity was $23 \mathrm{~cm}$ SL. We conclude that it is necessary to establish a minimum catch size in this reservoir based on the reproductive behavior of this species. Rev. Biol. Trop. 58 (4): 1577-1586. Epub 2010 December 01.
\end{abstract}

Key words: growth, reproduction, exploitation rate, Oreochromis aureus, Aguamilpa Reservoir, ELEFAN.

Tilapias of the family Cichlidae were introduced from Africa (Gómez-Márquez et al. 2003) and represent important social and economic benefits to rural communities (JiménezBadillo 2006). Reservoirs and lakes are the major tilapia fishery habitats around the world (Jiménez-Badillo 2004). While Mexico is a leading producer of tilapia in Latin America export levels are minimal (Ruiz Velazco-Arce et al. 2006). The total production in Mexico was of 80614 metric tons in 2007 (CONAPESCA 2008).

Aguamilpa Reservoir is located in the State of Nayarit, Mexico and has a storage capacity of $\sim 6950$ millions of cubic meters when full and a surface area of $\sim 11500$ ha (CFE 1989, Orbe-Mendoza et al. 2002). Commercial fishing started at the reservoir in the late 1990s, 
benefiting inhabitants in villages and smaller communities surrounding the reservoir (SAGARPA 2006). This fishery is now established and has helped to diversify economic activities. This State now ranks in the first place of tilapia production in Mexico, with an average of 2145 metric tons per year from 2000 through 2004 (Pérez-Velázquez et al. 2005).

Studies of tilapia fisheries have been produced for some reservoirs and lakes in Mexico. Orbe-Mendoza et al. (2002) determined some aspects of the biology and fishing of the blue tilapia in the Aguamilpa Reservoir. HernándezMontaño \& Orbe-Mendoza (2002) published on aspects of the blue tilapia and the Nile tilapia in the Zimapán Reservoir. Orbe-Mendoza et al. (1999) reported fishing activities of the tilapia in the El Infiernillo Reservoir. For this Reservoir, general and analytical models for tilapia management practices were developed (Jiménez-Badillo 2004). For this reservoir, modeling of age and growth of blue tilapia was performed by Jiménez-Badillo (2006). For Lake Coatetelco, Gómez-Márquez et al. (2008) did similar studies of the Nile tilapia.

The aim of this study was to evaluate growth parameters, mortality, population structure, reproductive season and size at first maturity of the blue tilapia in the Aguamilpa Reservoir, to provide basic information for the development of an appropriate fishery management of this specie.

\section{MATERIALS AND METHODS}

This study was carried out in the Aguamilpa reservoir $\left(21^{\circ} 53^{\prime}-21^{\circ} 23^{\prime} \mathrm{N}\right.$ and 104 $46^{\circ}$ '$104^{\circ} 25^{\prime}$ 'W) in Nayarit State, Mexico. Basic data was obtained from 2413 tilapia fish caught with gillnets ( 9.6 and $11.4 \mathrm{~cm}$ mesh) at commercial landing sites, from July 2000 through June 2001. Standard length (SL; $\pm 0.1 \mathrm{~cm})$ and total weight (TW; $\pm 0.1 \mathrm{~g}$ ) was recorded. At the time of the catch, the sex of each fish was registered. Additionally, surface temperature of the water was recorded with bucket thermometer $\left(\mathrm{T}^{\circ} \mathrm{C}\right.$; $\pm 0.1^{\circ} \mathrm{C}$ ) in different areas, covering the entire reservoir. Statistical analysis $\left(\chi^{2}\right)$ tested a null hypothesis of 1 female:1male (Sokal \& Rohlf 1979) with significance set at $\alpha=0.05$.

Relationship standard length to total weight: The SL/TW relationship for females, males and all specimens were analyzed with the power equation $\mathrm{WT}=a \mathrm{SL}^{b}$ (Ricker 1975), with the parameters of the models transformed by the $\log$ of the linear regression equation $(\mathrm{WT})=\log (a)+\log (\mathrm{SL}) b$, where $a$ is a constant and $b$ is the slope. In order to analyze models between sexes, a covariance analysis (ANCOVA) for elevations and slopes (Zar 1974) was used. The estimated $b$ parameter was evaluated with $t$-student test (Pauly 1983).

Growth parameters: The von Bertalanffy growth parameters (VBGF) for females, males and all specimens were estimated using the ELEFAN-I computer program, through frequency distributions of length (Gayanilo et al. 1996). The data were arbitrarily grouped into class intervals of $2 \mathrm{~cm}$ SL.

The third parameter $\left(t_{0}\right)$ of the VBFG was calculated independently, using the empirical formula of Pauly (1979), defined as:

$$
\log _{10}\left(-t_{0}\right)=-3.922-0.2752 \log _{10} L_{\infty}-1.038 \log _{10} k,
$$

where $t_{0}$ is the hypothetical age at which the fish length is zero, $L_{\infty}$ is the maximum allowable length in environmental condition and $k$ is the growth rate of the VBGF.

The longevity of individuals $\left(t_{\max }\right)$ was estimated using the following equation Pauly (1983):

$$
t_{\max }=\frac{3}{\mathrm{k}}+t_{0}
$$

The growth performance index $\left(\Phi^{\prime}\right)$ of Munro \& Pauly (1983) was calculated, using:

$$
\Phi^{\prime}=\log k+2 \log L_{\infty}
$$

Coefficients of mortality and exploitation: The total mortality coefficient $(Z)$ was estimated by a linearization curve to con- 
vert catch (Pauly 1984). Analysis used FiSAT software (Gayanilo et al. 1996).

The natural mortality coefficient $(M)$ was calculated through the equation proposed by Pauly (1980):

$$
\begin{gathered}
\log _{10} M=-0.0066-02979 \log _{10} L_{\infty}+0.6543 \log _{10} K+ \\
0.4634 \log _{10} T^{o} C
\end{gathered}
$$

where $\mathrm{T}^{\circ} \mathrm{C}$ is the average surface water temperature during the sampling period.

The $Z$ and $M$ estimates were used to calculate the fishing mortality coefficient $(F)$ with the formula $F=Z-M$ and the exploitation rate (E) cited by Sparre \& Venema (1997):

$$
E=\frac{F}{F+M}
$$

Relative condition factor: The relative condition factor $\left(K_{n}\right)$, was calculated monthly for females, males and total sample (Le Cren 1951):

$$
K_{n}=\frac{T W}{T W^{\prime}}
$$

where $T W$ is the weight of the fish and $T W^{\prime}$ is the estimated weight of the fish through the relationship SL/TW equation calculated for this population.

Reproductive cycle: The maturity stages in 977 individuals were assigned through morph chromatic scale proposed by Nikolsky (1963). The correlation between mean surface water temperature and the percentage of ripe (Phase IV) and spawning (Phase V) fish Nikolsky (1963) was determined with the nonparametric Spearman's rank correlation coefficient $r_{s}$ using an arcsine transformation of the percentages (Sokal \& Rohlf 1979).

The size at first maturity was determined when the height at which $50 \%$ of the cumulative relative frequency of specimens were in ripe stage (phase IV) of the maturity scale of Nikolsky (1963). To get the size at first maturi- ty the data were fitted to logistic model (Sparre \& Venema 1997):

$$
P=\frac{1}{1+e^{(\mathrm{a}-\mathrm{b} S L)}}
$$

where $P$ is the proportion of ripe individuals for size class, $a$ and $b$ are model parameters. Then the size at first maturity $(\mathrm{Lm} \% 50)$ was calculated:

$$
L m 50 \%=\frac{a}{b}
$$

Fecundity: The fecundity of 112 females was determined and for an estimation of total fecundity, ripe females were used, taking the total number of eggs contained in the gonads (Bagenal \& Tech 1978). The gonads of selected specimens were fixed in Gilson solution and oocytes were counted under a stereo microscope. Individual fecundity $(F)$ was related to the SL and TW by means of the $F=\mathrm{aSL} L^{\mathrm{b}}$ and $F=\mathrm{a}+T W \mathrm{~b}$ equations, where $a$ and $b$ are the model parameters.

\section{RESULTS}

Population structure: During the field work, 1371 males and 1042 females were captured for a sex ratio of 1male:0.76female. This was significantly different from the expected $1: 1$ ratio $\left(\chi^{2}=36.33, \mathrm{p}<0.0001\right)$.

The SL of the catch specimens ranged from 10 to $40.3 \mathrm{~cm}$, with a mean of 23.50 $\pm 3.34 \mathrm{~cm}$. Smaller sizes were found during February $(10.5 \mathrm{~cm} \mathrm{SL})$, April $(10.0 \mathrm{~cm} \mathrm{SL})$ and May 2001 (11 cm SL; Fig. 1). There were no significant differences between the size of males and females (U-test, $p>0.05$ ). The TW of the catch specimens ranged from 20 to $1800 \mathrm{~g}$, with a mean of $475.68 \pm 188.58 \mathrm{~g}$.

The monthly male-female sex ratio was statistically different from $1: 1\left(\chi^{2}\right.$-test; $\left.p<0.05\right)$ in July 2000 (1:0.59), December (1:0.66), January 2001 (1:0.57) and February (1:0.61). Also, the sex ratio was significantly higher for males $\left(\chi^{2}\right.$-test; $\left.\mathrm{p}<0.05\right)$ in two length frequencies (19$23 \mathrm{~cm}, 29-33 \mathrm{~cm})$. 

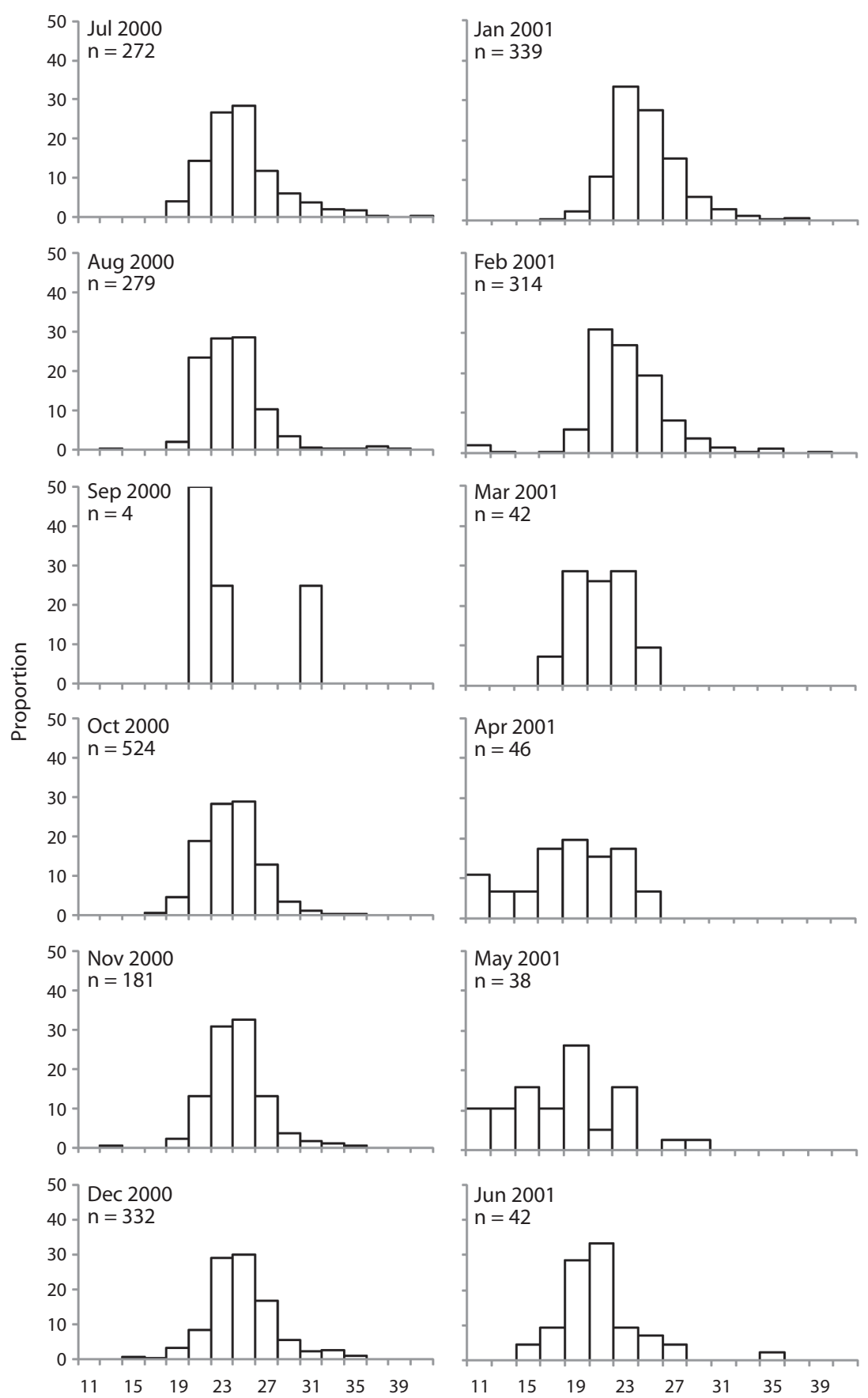

Standard length $(\mathrm{cm})$

Fig. 1. Frequency distribution of length monthly for the total specimens. 
Relationship of standard length to total weight: The models of the power relation $\mathrm{TW}=a \mathrm{SL}^{b}$ for females, males and total catch were highly significant (F-test, $\mathrm{p}<0.00001$ ); the same statistical differences were found between sex models (ANCOVA-test, $\mathrm{F}=8.43$, $\mathrm{p}<0.01)$. Thus this suggested the use of one model for males and another for females. Both females and males showed a value of $b<3$ (t-test, $\mathrm{p}<0.05$ ), which indicates a negative allometric growth (Table 1).

Growth parameters: Growth parameters of the VBGF estimates were: $L_{\infty}=41.8 \mathrm{~cm}$ and $k=0.35 /$ year for females, $L_{\infty}=43.21 \mathrm{~cm}$ and $\mathrm{k}=0.37 /$ year for males and total catch $L_{\infty}=43.33 \mathrm{~cm}$ and $k=0.36 /$ year. The growth performance index $\left(\Phi^{\prime}\right)$ was higher in males $\left(\Phi^{\prime}=2.839\right)$ than in females $\left(\Phi^{\prime}=2.786\right)$ and the total catch was 2.830 . The estimate of the third parameter of the VBGF $\left(t_{0}\right)$ was -0.43 years for females, -0.40years for males and -0.41years for the total catch. Longevity was higher for males (8.14 years) than females (7.70 years) and was nearly eight years for the total catch. The sizes estimated by the growth models for females and males did not differ significantly $\left(\chi^{2}=1323, p>0.05\right)$; therefore, we used a single model for both sexes.

Coefficients of mortality and exploitation: The total mortality coefficient $(Z)$ was 1.94/year, the natural mortality coefficient $(M)$ was 0.83 /year. The fishing mortality coefficient $(F)$ was $1.10 /$ year and the exploitation coefficient was $0.57 /$ year.
Relative condition factor: There were no significant differences in the relative condition index $\left(K_{n}\right)$ between sexes (ANOVA-test, $\mathrm{F}=1.058, \mathrm{p}>0.05)$. The values of this factor, on a monthly basis were significant different (ANOVA-test, $\mathrm{F}=12.245, \mathrm{p}<0.001$ ), the highest value was in May 2001 (Fig. 2).

Reproductive cycle: The greatest percentage of mature (Phase IV) individuals in the monthly catches occurred from January through April 2001 (>20\%) and the highest percentage of spawning (Phase V) individuals occurred from January through March and May 2001 (>40\%). Hence, the first four months of the year represent the peak reproductive period of blue tilapia in the reservoir. The range of temperature was $\sim 8^{\circ} \mathrm{C}\left(24.62^{\circ} \mathrm{C}\right.$ in December 2000 and $32.72^{\circ} \mathrm{C}$ in July 2000) with a mean of $28.54 \pm 2.77^{\circ} \mathrm{C}$. The percent of mature (Phase IV) tilapia was correlated with temperature

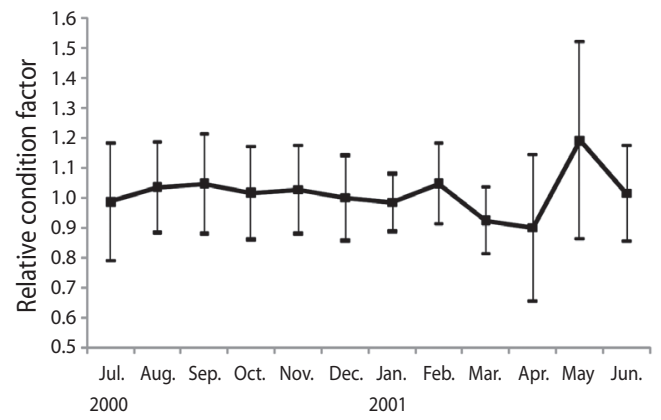

Fig. 2. Average of relative condition factor $( \pm$ standard deviation).

TABLE 1

Parameters estimated of standard length to total weight relationship

\begin{tabular}{lcrccccc}
\multicolumn{1}{r}{ Sex } & \multicolumn{2}{c}{ Standard length $(\mathrm{cm})$} & $\mathrm{a}$ & $\mathrm{b}$ & $\mathrm{b} \pm$ C.I. & $\mathrm{r}^{2}$ & \\
Females & Min & Max & & & & & \\
Males & 10.5 & 37.0 & 0.2101 & 2.4287 & 0.1370 & 0.8184 & 1042 \\
Both & 10.0 & 40.3 & 0.1374 & 2.5641 & 0.1426 & 0.8449 & 1371 \\
& 10.0 & 40.3 & 0.1625 & 2.5104 & 0.1404 & 0.8349 & 2413
\end{tabular}

$\mathbf{a}=$ model parameter, $\mathbf{b}=$ allometry coefficient, $\mathbf{C . I} .=$ confidence interval and $\mathbf{n}=$ sample size. 
$\left(r_{\mathrm{s}}=0.67, \mathrm{p}<0.001\right)$ and the percent of spawning stage (Phase V) tilapia was slightly correlated with water temperature $\left(r_{s}=0.64, p<0.05\right)$. The highest percent of mature and spawning tilapia occurred during January, February, March and May 2001, when monthly water temperature ranged between 25 and $28.3^{\circ} \mathrm{C}$ (Fig. 3).

The length at which $50 \%$ of the specimens were mature was $23 \mathrm{~cm}$. The smallest mature tilapia was $18 \mathrm{~cm}$ (Fig. 4).

Fecundity: The fecundity ranged from 118 eggs $(22.7 \mathrm{~cm} \mathrm{SL})$ to $5753 \mathrm{eggs}(29 \mathrm{~cm}$ SL), with a mean during study period of 1 $231 \pm 802$ eggs. No significant relationship was found between SL and fecundity $\left(\mathrm{r}^{2}=0.02\right.$, $\mathrm{F}=3.27$, $\mathrm{p}>0.05$; Fig. 5). There was no relationship between fecundity and TW $\left(\mathrm{r}^{2}=0.002\right.$, $\mathrm{F}=0.260, \mathrm{p}>0.05)$. The highest average fecundity occurred in females with an SL of $28-30 \mathrm{~cm}$ (2 268 \pm 232 eggs) and the lowest in females with a SL of $20-22 \mathrm{~cm}(938 \pm 519 \mathrm{eggs})$.

\section{DISCUSSION}

Blue tilapias (O. aureus) in Aguamilpa Reservoir were larger than those reported in $\mathrm{El}$ Infiernillo Reservoir (15 to $30.5 \mathrm{~cm} \mathrm{SL}$ ) in the State of Michoacan (Jiménez-Badillo 2006) and similar those found by Ramos-Cruz (1995) in the Benito Juárez dam (10.6 to $39.8 \mathrm{~cm}$ total length). This may be related to differences among fishing gear used at Aguamilpa Reservoir than other regions of Mexico. The size reported in $O$. niloticus for several reservoirs and water bodies of Mexico are lower than those found in the present study, for example in Coatetelco lake, Morelos the size ranged was from 11.7 to $20.6 \mathrm{~cm}$ total length (GómezMarquez et al. 2003).

Carlander (1969) points out that, regarding the relationship of SL to TW, the values of $b$ should vary between 2.5 and 3.5. For blue tilapia in Aguamilpa, estimates of $b$ for males, females and total catch growth rate indicate a negative allometric $(b<3)$, which is similar to reservoirs in Cuba (Fonticiella 2000), El Infiernillo (Jiménez-Badillo 2006) and Benito Juárez Reservoir in Oaxaca (Ramos-Cruz 1995). Allometric growth is often common in species of the genus Oreochromis, as reported for the Nile tilapia in Lake Coatetelco in Morelos (Gómez-Márquez et al. 2008) and the Shanawan Channel in

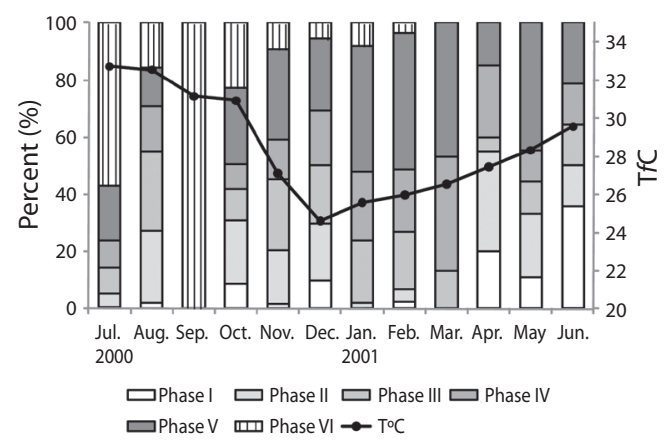

Fig. 3. Reproductive pattern and monthly surface water temperature $\left(\mathrm{T}^{\circ} \mathrm{C}\right)$.

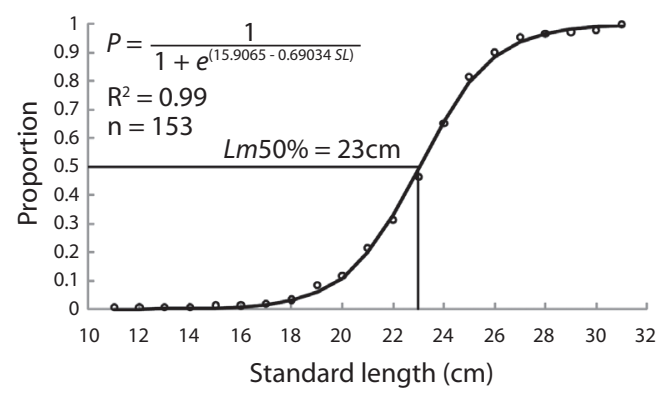

Fig. 4. Size at first sexual maturity of Oreochromis aureus.

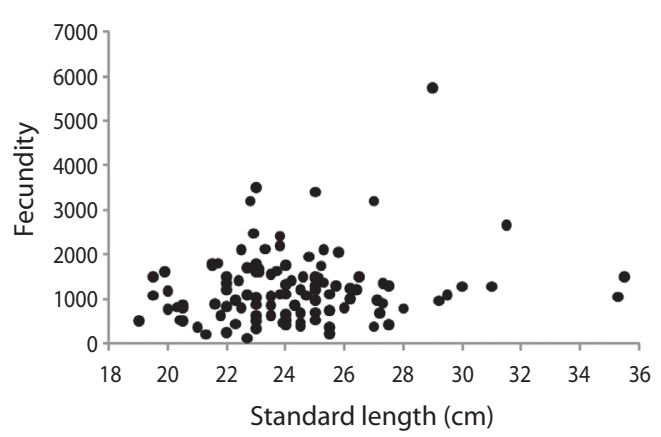

Fig. 5. The standard length to fecundity relationship of females. 
Egypt (Khallaf et al. 2003) and for the longfin tilapia (O. macrochir) in the Okavango Delta of Botswana (Booth \& Merron 1996) and Lake Metztitlan, Ibáñez (2004) found that allometric coefficient may vary through year reaching values of three when environmental conditions are suitable for species. The allometric growth for different species of tilapia has been attributed mainly to problems of food and fish density in the water (Murphy et al. 1991). The significant differences found between the SL/TW models for males and females has not been reported in earlier works except for Fonticiella (2000) who indicates that these differences may be related to sexual dimorphism and behavior.

Growth parameters of the VBGF for the total catch were $L_{\infty}=43.33 \mathrm{~cm} \mathrm{SL}, k=0.36 /$ year and $t_{0}=-0.43$ years. With no significant differences between sex models, there are not evidence indicating a growth differential between males and females. For this reservoir, Orbe-Mendoza et al. (2002) estimated growth parameters of $L_{\infty}=36.5 \mathrm{~cm}$ SL and $k=0.6 /$ year and calculated growth to be faster than reported in our study; however, we found a greater range of sizes than reported by Orbe-Mendoza et al. (2002). This permits better estimates of parameters in the VBGF, compared with similar studies with blue tilapia in other reservoirs in Mexico. Table 2 indicates that there may be differences in the growth of this species in different areas caused by factors such as temperature, availability of food, metabolic activity and reproductive activity, among other differences as reflected in parameters $L_{\infty}$ and $k$ (Isaac 1990, Jiménez-Badillo 2006).
The natural mortality coefficient (0.82/ year) was lower than the fishing mortality coefficient (1.12/year). The exploitation rate was $0.57 /$ year, higher than the optimal level ( $E=0.5 /$ year) proposed by Gulland (1971). This suggests that blue tilapia overfishing during our study period although the former possibility is function of the gear fishing characteristics, effort and is necessary evaluate it in futures studies. Orbe-Mendoza et al. (2002) reported an exploitation rate of $0.47 /$ year, that overfishing was not present at that time. Since 2001 catches have increased and now exceed 2000 metric tons per year and it is likely that the fishery is now overexploiting the resource (SAGARPA 2006).

Blue tilapia spawning is partially asynchronous, that is, the gonads are not fully mature at the same time (Jiménez-Badillo 2006). Spawning can be sequential most of the year, but we found more mature females from January through April 2001, suggesting multiple spawns during the year while the highest frequency of spawning occurring from January to May 2001. Orbe-Mendoza et al. (2002) reported that more than $85 \%$ of females are mature or spawning during April and May.

In El Infiernillo Reservoir, reproductive peaks occurred from May through August and October through January (Jiménez-Badillo 2006). In the Zimapán Reservoir in Hidalgo, peak spawning activity of tilapia was similar to this study, March to May and September (Hernández-Montaño \& Orbe-Mendoza 2002).

Highest values or the relative condition factor $\left(K_{n}\right)$ occurred during September 2000

TABLE 2

Growth parameters for Oreochromis aureus in four reservoirs in Mexico

\begin{tabular}{lccccl} 
& $L_{\infty}(\mathrm{cm})$ & $k\left(\mathrm{yr}^{-1}\right)$ & $t_{0}(\mathrm{yr})$ & $\Phi^{\prime}$ & \multicolumn{1}{c}{ Reservoir } \\
This study & 43.3 & 0.32 & -0.430 & 2.83 & Aguamilpa, Nayarit \\
Jiménez-Badillo, 2006 & 47.9 & 0.46 & -0.055 & 3.02 & Infiernillo, Michoacan \\
Hernández-Montaño \& Orbe-Mendoza, 2002 & 41.3 & 0.66 & -0.250 & 3.05 & Zimapan, Hidalgo \\
Orbe-Mendoza et al., 2002 & 36.5 & 0.60 & & 2.90 & Aguamilpa, Nayarit \\
Ramos-Cruz, 1995 & 29.6 & 0.22 & -0.904 & 2.29 & Benito Juarez, Oaxaca
\end{tabular}

$\boldsymbol{L}_{\infty}=$ maximum allowable length, $\boldsymbol{k}=$ the growth rate, $\boldsymbol{t}_{\boldsymbol{0}}=$ hypothetical age at which the fish length is zero and $\boldsymbol{\Phi}^{\prime}=$ growth performance index. 
and February and May 2001, which were the months with the largest percent of spawning and post-spawning females.

The peak period of reproductive activity of blue tilapia started when the surface water temperature was in the range of $25-28.3^{\circ} \mathrm{C}$. Saavedra-Martínez (2006) found that the reproduction of tilapia under cultivated conditions occurred at temperatures ranging from $26-29^{\circ} \mathrm{C}$. In the present study we found that fecundity can vary in one size and ranged from 118 eggs/ fish $(22.7 \mathrm{~cm} \mathrm{SL})$ to $5753 \mathrm{eggs} /$ fish $(29 \mathrm{~cm} \mathrm{SL})$, with no other published studies of fecundity for blue tilapia in environmental conditions. For the Nile tilapia in Lake Chila in Veracruz, fecundity ranged from 1505 to 5559 eggs for females range from 23.5 to $32.5 \mathrm{~cm}$ (BasurtoOrigel 1994). In the Coatetelco Lake, Mexico the fecundity in O. niloticus varied from 104 to 373 eggs/fish (Gómez-Marquez et al. 2003) and the size range was lower that present work (12.5 to $20.9 \mathrm{~cm}$ total length). Peña-Mendoza $e t$ al. (2005) determined the fecundity in O. niloticus in Emiliano Zapata dam, Morelos, Mexico, found that varied between 243 to $847 \mathrm{eggs} /$ fish with size ranged from 14 to $22 \mathrm{~cm}$ total length. The fecundity to Nile tilapia in the Opa Reservoir in Nigeria reported by Komolafe \& Arawomo (2007) was between 73 eggs $(18.8 \mathrm{~cm})$ to 1810 eggs $(29.7 \mathrm{~cm})$.

The size at first maturity of blue tilapia in the Aguamilpa Reservoir was $23 \mathrm{~cm}$ SL. This is no different from other reports: $25 \mathrm{~cm}$ (OrbeMendoza et al. 2002) and 22cm (Ramos-Cruz 1995), given that size at maturity probability is affected by fishing or environmental conditions like temperature and available of food. For the Aguamilpa Reservoir, the minimum capture size of $25 \mathrm{~cm}$ for tilapia, which was proposed by SAGARPA (2006) would protect $80 \%$ of the mature individuals; however, the size is not yet been regulated.

Although the catch of blue tilapia in the Aguamilpa reservoir has increased to more than twice the reported catch of 2000 and 2001, the catch might have been sustained by repopulation programs conducted in the reservoir (SAGARPA 2006). However, this is no comfort to the fishery since there are clear indications of overexploitation of the resource. To maintain a sustainable fishery, a minimum capture size, based on the information available about maturity and size and on appropriate size of gill nets, is needed.

\section{ACKNOWLEDGMENTS}

This investigation was partially supported by Secretaría de Desarrollo Rural (SEDER) of Nayarit Government. The authors thank Jorge A. López-Rocha for his comments in an earlier version of the manuscript. J.I.V.A. and J.M.J.R.V.A. received CONACYT and PIFIIPN doctoral fellowships. Thank to Ira Fogel by editing the document and review the English text. The authors thank the valuable comments of two anonymous reviewers.

\section{RESUMEN}

Los parámetros de crecimiento, reproducción y mortalidad de Oreochormis aureus en el embalse de Aguamilpa, México fueron determinados. Un total de 2413 organismos se recolectaron entre julio de 2000 y junio de 2001, de los cuales 1371 fueron machos y 1042 hembras. Se analizó la relación longitud estándar (LE) y peso total (PT) mediante modelos potenciales. Los parámetros de crecimiento de la ecuación de von Bertalanffy fueron estimados usando la distribución de frecuencia de tallas con ayuda del programa ELEFAN-I. Finalmente se determinó el ciclo reproductivo, talla de primera madurez y fecundidad. Los resultados indicaron que tanto hembras como machos presentaron crecimiento alométrico negativo. Se encontraron diferencias significativas entre hembras y machos para la relación LE-PT sugiriendo modelos separados por sexo. No existieron diferencias significativas en el crecimiento por sexo y la tasa de explotación estimada (0.57/año) sugiere que la pesquería durante el periodo de estudio mostró signos de sobreexplotación. La tilapia azul se reproduce a lo largo del año con mayor intensidad entre enero y mayo. Por lo tanto se concluye que es necesario establecer una talla mínima de captura con base en el comportamiento reproductivo de la especie.

Palabras clave: crecimiento, reproducción, tasa de explotación, Oreochromis aureus, embalse de Aguamilpa, ELEFAN. 


\section{REFERENCES}

Bagenal, T.B. \& F.W. Tech. 1978. Age and Growth, p. 101136. In T.B. Bagenal (ed.). Methods for assessment of fish production in freshwater. Blackwell, Oxford, England.

Basurto-Origel, M. 1994. Aspectos reproductivos de la tilapia Oreochromis niloticus (Linneo) en la Laguna de Chila, Veracruz. BIOTAM. 6: 1-3.

Booth, A.J. \& G.S. Merron. 1996. The age and growth of the greenhead tilapia Oreochromis macrochir (Pisces: Cichlidae) from the Okavango Delta, Botswana. Hydrobiol. 321: 29-34.

Carlander, K. 1969. Handbook of freshwater fishery biology. The Iowa State University, Iowa, USA.

CFE. 1989. Manifestación de Impacto Ambiental Modalidad Intermedia. Comisión Federal de Electricidad. Gerencia del Proyecto Hidroeléctrico, P.H. Aguamilpa, Nayarit, México D.F., México.

CONAPESCA. 2008. Anuario Estadístico. Comisión Nacional de Acuacultura, México.

Fonticiella, D.W. 2000. Peso estandar de la tilapia (Orechromis aureus Steindachner) en Cuba. Rev. Prod. Anim. 12: 5-12.

Gayanilo, F.C., P. Sparre \& D. Pauly. 1996. The FAOICLARM Stock Assessment tools (FiSAT) users guide, FAO Computerized information series (Fisheries) No. 8. FAO, Rome, Italy.

Gómez-Márquez, J.L., B. Peña-Mendoza, I.H. SalgadoUgarte \& M. Guzmán-Arroyo. 2003. Reproductive aspects of Oreochromis niloticus (Perciformes: Cichlidae) at Coatetelco lake, Morelos, Mexico. Rev. Biol. Trop. 51: 221-228.

Gómez-Márquez, J.L., B. Peña-Mendoza, I.H. SalgadoUgarte \& J.L. Arredondo-Figueroa. 2008. Age and growth of the tilapia, Oreochromis niloticus (Perciformes: Cichlidae) from a tropical shallow lake in Mexico. Rev. Biol. Trop. 56: 875-884.

Gulland, J.A. 1971. Fish resources of the ocean. Fishing New Books, Surrey, London, England.

Hernández-Montaño, D. \& A. Orbe-Mendoza. 2002. Presa Fernando Hiriart Balderrama (Zimapán) HidalgoQuerétaro, México: Opciones para su manejo, p. 437-457. In G. de la Lanza-Espino and J.L. GarcíaCalderón (eds.). Lagos y Presas de México. AGT, México D.F., México.
Ibáñez, A.L. 2004. Impact of the timing of stocking on growth and allometric index in aquaculture-based fisheries. Fish. Manag. Ecol. 11: 81-87.

Isaac, V. 1990. The accuracy of some length-based methods for fish population studies. ICLARM. Tech. Rep. 27: $1-81$.

Jiménez-Badillo, L. 2004. Application of holistic and analytical models for the management of tilapia fisheries in reservoir. Hidrobiológica 14: 61-68.

Jiménez-Badillo, L. 2006. Age-growth models for tilapia Oreochromis aureus (Perciformes: Cichlidae) of the Infiernillo reservoir, Mexico and reproductive behavior. Rev. Biol. Trop. 54: 577-588.

Khallaf, E.A., M. Galal \& M. Authman. 2003. The biology of Oreochormis niloticus in a polluted canal. Ecotoxicol. 12: 405-416.

Komolafe, O.O. \& G.A.O. Arawomo. 2007. Reproductive strategy of Oreochromis niloticus (Pisces: Cichlidae) in Opa reservoir, Ile-Ife, Nigeria. Rev. Biol. Trop. 55: 595-602

Le Cren, E.D. 1951. The lenght-weight relationship and seasonal cycle in gonad weight and condition in the perch (Perca fluviatilis). J. Anim. Ecol. 20: 201-219.

Munro, J. \& D. Pauly. 1983. A simple method for comparing growth of fishes and invertebrates. ICLARM. Fishbyte 1: 5-6.

Murphy, B.R., D. Willis \& T.A. Springer. 1991. The relative weight index in fisheries management: Status and needs. Fisheries 16: 30-38.

Nikolsky, G.V. 1963. The ecology of fishes. Academic, London, England.

Orbe-Mendoza, A.A., C. Romero-Acosta \& J. AcevedoGarcía. 1999. Producción y Rendimiento Pesquero en la Presa Lic. Adolfo López Mateos (El Infierni1lo), Michoacán-Guerrero, México. Hidrobiológica 9: $1-8$.

Orbe-Mendoza, A.A., D. Hernández-Montaño, J. AcevedoGarcia \& M. Guzman-Arroyo. 2002. Presa Aguamilpa, Nayarit, México, p. 402-420. In G. de la Lanza-Espino and J.L. García-Calderón (eds.). Lagos y Presas de México. AGT, México D.F., México.

Pauly, D. 1979. Theory and management of tropical multispecies stocks: a review with emphasis on the Southeast Asian demersal fisheries. ICLARM Stud. Rev. 1: 1-35 
Pauly, D. 1980. On the interrelationships between natural mortality, growth parameters and mean environmental temperature in 175 fish stocks. J. du Con. Int. pour I’Exp. de la Mer. 39: 175-192.

Pauly, D. 1983. Some simple methods for the assessment of tropical fish stocks. FAO, Fish. Tech. Paper 234, Rome, Italy.

Pauly, D. 1984. Length-converted catch curves: a powerful tool for fisheries research in the tropics (Part II). ICLARM. Fishbyte 2: 17-19.

Peña-Mendoza, B., J.L. Gómez-Márquez, I.H. SalgadoHugarte \& D. Ramírez-Noguera. 2005. Reproductive biology of Oreochromis niloticus (Perciformes: Cichlidae) at Emiliano Zapata dam, Morelos, Mexico. Rev. Biol. Trop. 53: 515-522.

Pérez-Velázquez, P.A., P. Ulloa-Ramírez \& J.L. PatiñoValencia. 2005. Diagnóstico de la pesquería comercial de escama en la Presa Hidroeléctrica Aguamilpa, Nayarit. Centro Regional de Investigación Pesquera, Instituto Nacional de Pesca, Bahía de Banderas, Nayarit, México.

Ramos-Cruz, S. 1995. Reproducción y crecimiento de la mojarra tilapia (Oreochromis aureus) en la presa Benito Juárez, Oaxaca, México en 1993. INPSEMARNAP. Ciencia Pesquera 11: 54-61.
Ricker, W.E. 1975. Computation and interpretation of biological statistics of fish populations. Bull. Fish. Res. Bd. Canada 191: 1-382.

Ruiz Velázco-Arce, J.M., R. Tapia-Varela, J.R. GarcíaPartida \& H. González-Vega. 2006. Evaluación de un cultivo semi-intensivo de tilapia (Oreochromis niloticus) en tanques circulares con aguas termales. REDVET 7: 1-12.

Saavedra-Martínez, M.A. 2006. Manejo del cultivo de tilapia. Managua, Nicaragua. USAID, University of Rhode Island, University of Hawaii and CIDEA, USA.

SAGARPA. 2006. Presa de Aguamilpa, Nayarit. Carta Nacional Pesquera. Diario Oficial de la Federación. México.

Sokal, R. \& J. Rohlf. 1979. Biometry: the principles and practice of statistics in biological research. CA. Blume, California, USA.

Sparre, P. \& S.C. Venema. 1997. Introduction to tropical fish stock assessment. Manual. Food and Agricultural Organization of the United Nations. Part 1. FAO, Fish. Tech. Paper, Rome, Italy.

Zar, H.J. 1974. Biostatistical analysis. Prentice-Hall, Englewood Cliffs, New York, USA. 